\title{
Wild boars (Sus scrofa) as bioindicators of environmental levels of selenium in Poland
}

\author{
E. Nowakowska, B. Pilarczyk ${ }^{1}$, R. Pilarczyk ${ }^{2}$, A. Tomza-Marciniak ${ }^{1}$, \\ M. Bąkowska', A. Marciniak ${ }^{3}$ \\ ${ }^{1}$ Department of Animal Reproduction Biotechnology and Environmental Hygiene, \\ West Pomeranian University of Technology in Szczecin, Judyma 6, 71-466 Szczecin, Poland \\ ${ }^{2}$ Laboratory of Biostatistics, West Pomeranian University of Technology in Szczecin, \\ Judyma 10, 71-466 Szczecin, Poland \\ ${ }^{3}$ Institute of Technology and Life Sciences, West Pomeranian Research Centre, \\ Czesława 9, 71-504 Szczecin, Poland
}

\begin{abstract}
The objective of the study was to determine selenium content in selected organs (liver, kidney) of wild boars from different regions of Poland. Materials for the study were obtained from 28 sites located in 16 provinces of Poland. Selenium concentrations in organs were determined using spectrofluorometric methods after wet mineralization in $\mathrm{HNO}_{3}$ and $\mathrm{HClO}_{4}$ mixture. Mean selenium concentrations in the investigated wild boars from Poland were $0.230 \mu \mathrm{g} / \mathrm{g}$ wet weight in the liver and 1.327 $\mu \mathrm{g} / \mathrm{g}$ w.w. in the kidneys. Hepatic and nephric Se concentrations ranged from $0.036-0.626 \mu \mathrm{g} / \mathrm{g}$ w.w. and 0.322-4.286 $\mu \mathrm{g} / \mathrm{g}$ w.w., respectively. Selenium concentrations in the wild boars differed considerably according to geographical location. Concentrations of selenium were highest in wild boars from south-eastern provinces and lowest in animals from northern provinces. Most of Poland's area is environmentally deficient in this trace element, as evidenced by marginal selenium levels in the organs of the wild boars.
\end{abstract}

Key words: selenium, liver, kidney, wild boar (Sus scrofa), bioindicator, Poland

\section{Introduction}

Selenium is unevenly distributed in nature; some areas have selenium-rich soils, others have soils deficient in this element. Most soils in Europe, including some regions of Poland, are considered deficient in selenium (Kabata-Pendias and Pendias 1999, Pilarczyk et al. 2009, Flueck et al. 2012, Pilarczyk et al. 2013) as are other countries, eg China, Turkey, New Zealand and Scandinavia (Yläranta 1990, Beytut et al.
2002, Mäkelä-Kurtto and Sipolla 2002, Hartikainen 2005). As selenium plays an important role in the upper links of the trophic chain, in the nutrition of both animals and humans, it is necessary to develop a soil selenium map for different regions of the country.

In many animals prolonged selenium deficiency contributes to reductions in the litter size, body condition, embryonic survival, placental retention, growth rate, increase in neonatal mortality, as well as the vetarded attainment of sexual maturity (Flueck and

Correspondence to: A. Tomza-Marciniak, e-mail: agnieszka.tomza-marciniak@zut.edu.pl 
Smith-Flueck 2008, Flueck et al. 2012). One of the reasons for the decline in the populations of some free-living animals - in addition to irreversible changes to their habitat, widespread farming, changes in crop structure and predation - is decreased animal immunity as a result of selenium deficiencies (Flueck et al. 2012). Free-living animals, thanks to their close integration with their habitats throughout their lives, are good indicators of environmental selenium content.

Some of the factors that make the wild boar well suited as a bioindicator are the tight integration with the natural environment, large population sizes, broad territorial range and their ease of collection, as one of the principal game animals in the country. The wild boar's selenium status depends on the amount and bioavailability of this element in the soil to the plants. The content of this trace element in plants that are the principal food of wild boars depends on the species, type of soil, amount and chemical form of soil selenium, and the climate and growing conditions (Terry et al. 2000).

The objective of the study was to determine Se content in selected organs of wild boars from different regions of Poland and establish the Se status of animals based on concentration of this element in liver and kidney.

\section{Materials and Methods}

\section{Reagents}

Most chemicals were obtained from Chempur ${ }^{\circledR}$ apart from 2,3-diaminonaphthalene (DAN) which was obtained from Sigma-Aldrich. The analytical procedure was verified by determining selenium concentration in the reference material NCS ZC 71001 (bovine liver) (China National Analysis Center for Iron and Steel, Beijing, China). All chemicals used were of analytical reagent grade.

\section{Samples}

The experimental material used in this study consisted of a total of 350 (175 liver and 175 kidney) samples collected from 175 wild boars (Sus scrofa) of both sexes shot during the hunting season between 15 August 2009 and 15 January 2010 from 28 sites located in 16 provinces of Poland. No selenium-supplemented salt licks were used in the Hunting Clubs from which the material was obtained. The timing and limits of the hunting conformed to the Regulation of the Minister of Environment of 16
March 2005 establishing seasons of hunting warrantable animals (Journal of Laws, 25 March 2005). Animals from different provinces were in the same age range of 2 to 4 years. The hunters determined the age of the animals using the key provided by Przybylski (2008)

All tissue samples were homogenized and then frozen $\left(-20^{\circ} \mathrm{C}\right)$, and stored in the laboratory until analysis. During collection of samples for chemical determinations we also collected samples for dry matter determination (samples of $1 \mathrm{~g}$ w.w. were dried at $105^{\circ} \mathrm{C}$ until they became a solid mass).

\section{Chemical analyses}

Selenium concentrations in organs were determined using spectrofluorometric methods (Grzebula and Witkowski 1977). The samples were digested in $3.5 \mathrm{ml} \mathrm{HNO}_{3}$ at $230^{\circ} \mathrm{C}$ for $180 \mathrm{~min}$ and in $3 \mathrm{ml} \mathrm{HClO}_{4}$ at $310^{\circ} \mathrm{C}$ for $20 \mathrm{~min}$. Finally, $3 \mathrm{ml} 9 \% \mathrm{HCl}$ was added to reduce $\mathrm{Se}^{6+}$ to $\mathrm{Se}^{4+}$. Selenium was derived with 2,3-diaminonaphthalene (Sigma-Aldrich) under conditions of controlled $\mathrm{pH}$ (pH 1-2) with the formation of a selenodiazole complex. This complex was extracted into cyclohexane. EDTA and hydroxylamine hydrochlorine were used as masking agents. Se concentration was determined fluorometrically using a Shimadzu RF-5001 PC spectrofluorophotometer. The excitation wavelength was $376 \mathrm{~nm}$ and the fluorescence emission wavelength was $518 \mathrm{~nm}$.

The calibration curve was calculated using a series of standard solutions containing Se at concentrations from 0.004 to $1.500 \mu \mathrm{g} / \mathrm{mL}$ The correlation coefficients for the calibration curve were at least 0.998, showing good linear relationship throughout the ranges of concentrations studied. The limits of detection (LoD) were calculated with three times the standard deviation of the 10 individually prepared blank solutions. The LoD value was $0.003 \mu \mathrm{g} / \mathrm{mL}$.

The accuracy of the method was verified using certified reference material NCS ZC 71001 (bovine liver) (China National Analysis Center for Iron and Steel, Beijing, China) and the Se concentration obtained was $91.1 \%$ of the reference values. The precision of the method was evaluated by determination of Se concentration in standard solutions (10 repeated determinations of one sample and quantifying selenium five times in each extract). The precision was indicated as the mean RSD\% for each extract, and the reproducibility is indicated as total mean RSD\% for all the extracts. In our study precision and reproducibility of analysis was respectively $2.7 \%$ and $3.0 \%$. 
Table 1. Mean selenium concentration in the liver of wild boars from different provinces.

\begin{tabular}{|c|c|c|c|c|c|c|c|}
\hline \multirow{2}{*}{ Province } & \multirow{2}{*}{$\mathrm{N}$} & \multicolumn{3}{|c|}{ Se content, $\mu \mathrm{g} / \mathrm{g}$ w.w. } & \multicolumn{3}{|c|}{ Se content, $\mu \mathrm{g} / \mathrm{g}$ d.w. } \\
\hline & & $\bar{x}$ & SEM & Range & $\bar{x}$ & SEM & Range \\
\hline Dolnośląskie (1) & 10 & 0.217 & 0.015 & $0.180-0.341$ & 0.740 & 0.051 & $0.614-1.162$ \\
\hline Kujawsko-Pomorskie (2) & 10 & 0.214 & 0.015 & $0.137-0.304$ & 0.729 & 0.050 & $0.467-1.038$ \\
\hline Lubelskie (3) & 10 & 0.346 & 0.034 & $0.186-0.500$ & 1.179 & 0.114 & $0.634-1.706$ \\
\hline Lubuskie (4) & 11 & 0.177 & 0.015 & $0.112-0.260$ & 0.603 & 0.051 & $0.382-0.887$ \\
\hline Łódzkie (5) & 10 & 0.170 & 0.016 & $0.105-0.219$ & 0.580 & 0.054 & $0.358-0.747$ \\
\hline Małopolskie (6) & 10 & 0.375 & 0.055 & $0.088-0.626$ & 1.278 & 0.189 & $0.301-2.135$ \\
\hline Mazowieckie (7) & 10 & 0.165 & 0.029 & $0.036-0.271$ & 0.562 & 0.099 & $0.123-0.924$ \\
\hline Opolskie (8) & 10 & 0.265 & 0.017 & $0.202-0.357$ & 0.903 & 0.056 & $0.691-1.217$ \\
\hline Podkarpackie (9) & 10 & 0.298 & 0.009 & $0.252-0.350$ & 1.017 & 0.032 & $0.859-1.193$ \\
\hline Podlaskie (10) & 12 & 0.186 & 0.025 & $0.065-0.324$ & 0.635 & 0.084 & $0.223-1.104$ \\
\hline Pomorskie (11) & 11 & 0.128 & 0.012 & $0.063-0.205$ & 0.437 & 0.041 & $0.216-0.698$ \\
\hline Śląskie (12) & 10 & 0.190 & 0.025 & $0.061-0.316$ & 0.650 & 0.084 & $0.207-1.079$ \\
\hline Świętokrzyskie (13) & 10 & 0.481 & 0.014 & $0.406-0.554$ & 1.642 & 0.049 & $1.386-1.890$ \\
\hline Warmińsko-Mazurskie (14) & 9 & 0.133 & 0.011 & $0.080-0.186$ & 0.453 & 0.039 & $0.273-0.635$ \\
\hline Wielkopolskie (15) & 12 & 0.260 & 0.023 & $0.101-0.367$ & 0.888 & 0.079 & $0.346-1.253$ \\
\hline Zachodniopomorskie (16) & 20 & 0.154 & 0.016 & $0.056-0.377$ & 0.527 & 0.055 & $0.192-1.286$ \\
\hline Total & 175 & 0.230 & 0.009 & $0.036-0.626$ & 0.784 & 0.030 & $0.123-2.135$ \\
\hline
\end{tabular}

Significant differences $3,6,13: 1,2,4,5,7,8,10,11,12,14,15,16^{* *} ; 3,6,9: 13^{* *} ; 11: 1,2,8,9,15^{* *} ; 8,9,15: 4,5,7,14,16^{* * ;} 9: 6$, at $* * \mathrm{p} \leq 0.01 ; * \mathrm{p} \leq 0.05$ $10,12 * * ; 8,15: 10,12 * ; 1,2: 9,14,16^{*}$

Table 2. Mean selenium concentration in the kidneys of wild boars from different provinces.

\begin{tabular}{lccccccc}
\hline & & \multicolumn{3}{c}{ Se content, $\mu \mathrm{g} / \mathrm{g}$ w.w. } & \multicolumn{3}{c}{ Se content, $\mu \mathrm{g} / \mathrm{g}$ d.w. } \\
\cline { 5 - 8 } \multicolumn{1}{c}{ Province } & $\mathrm{N}$ & $\bar{x}$ & $\mathrm{SEM}$ & Range & $\bar{x}$ & SEM & Range \\
\hline Dolnośląskie (1) & 10 & 2.065 & 0.239 & $1.155-4.056$ & 7.045 & 0.815 & $3.941-13.839$ \\
Kujawsko-Pomorskie (2) & 10 & 0.960 & 0.060 & $0.734-1.284$ & 3.277 & 0.206 & $2.506-4.380$ \\
Lubelskie (3) & 10 & 2.322 & 0.031 & $2.189-2.455$ & 7.923 & 0.105 & $7.469-8.375$ \\
Lubuskie (4) & 11 & 1.105 & 0.069 & $0.635-1.526$ & 3.769 & 0.236 & $2.165-5.206$ \\
Lódzkie (5) & 10 & 0.890 & 0.099 & $0.322-1.387$ & 3.036 & 0.336 & $1.109-4.732$ \\
Małopolskie (6) & 10 & 1.715 & 0.150 & $0.697-2.679$ & 5.851 & 0.511 & $2.378-9.140$ \\
Mazowieckie (7) & 10 & 0.970 & 0.144 & $0.391-1.530$ & 3.309 & 0.490 & $1.334-5.221$ \\
Opolskie (8) & 10 & 1.415 & 0.073 & $1.053-1.690$ & 4.827 & 0.250 & $3.592-5.766$ \\
Podkarpackie (9) & 10 & 1.269 & 0.072 & $0.751-1.524$ & 4.331 & 0.247 & $2.561-5.201$ \\
Podlaskie (10) & 12 & 1.210 & 0.099 & $0.682-1.777$ & 4.127 & 0.337 & $2.327-6.063$ \\
Pomorskie (11) & 11 & 0.669 & 0.061 & $0.201-0.955$ & 2.284 & 0.207 & $1.140-3.259$ \\
Ślaskie (12) & 10 & 1.246 & 0.052 & $1.128-1.630$ & 4.252 & 0.178 & $3.850-5.561$ \\
Świętokrzyskie (13) & 10 & 2.693 & 0.224 & $1.715-4.286$ & 9.189 & 0.765 & $5.851-14.624$ \\
Warmińsko-Mazurskie (14) & 9 & 1.017 & 0.078 & $0.702-1.425$ & 3.469 & 0.267 & $2.396-4.861$ \\
Wielkopolskie (15) & 12 & 1.130 & 0.083 & $0.768-1.542$ & 3.854 & 0.285 & $2.620-5.263$ \\
Zachodniopomorskie (16) & 20 & 1.002 & 0.073 & $0.415-1.430$ & 3.420 & 0.248 & $1.417-4.879$ \\
\hline Total & 175 & 1.327 & 0.048 & $0.322-4.286$ & 4.528 & 0.164 & $1.098-14.624$ \\
\hline
\end{tabular}

Significant differences $1,3,13: 2,4,5,6,7,8,9,10,11,12,14,15,16^{* *} ; 1: 13^{* *} ; 3: 13^{*} ; 6: 2,4,5,7,9,10,11,12,14,15,16^{* *} ; 11: 4,8,9$, at $* * \mathrm{p} \leq 0.01 ; * \mathrm{p} \leq 0.05$ $10,12,15^{* *} ; 11: 14,16^{*} ; 8: 2,5,7,16^{* *} ; 8: 14 * ; 9,10 ; 12: 5^{*}$

\section{Statistical data analyses}

The results were analysed using STATISTICA 9.0 PL software. Tables show arithmetic means $(\bar{x})$, standard error of the mean (SEM), and minimal and maximal values (range). The normality of variable distributions was tested by Shapiro-Wilk test, after which variables not normally distributed were adjusted to a normal distribution by logarithmic transformation. Statistical analysis was performed with log-transformed data using one-way analysis of variance to test the effect of each variable separately. Sig- 
Table 3. Selenium concentration in liver (L), kidney (K) of wild boar and soil from different provinces.

\begin{tabular}{|c|c|c|c|c|}
\hline \multirow{3}{*}{ Province } & \multicolumn{3}{|c|}{ Se concentration $\mu \mathrm{g} / \mathrm{g} \mathrm{dw}$} & \multirow{3}{*}{ References } \\
\hline & \multicolumn{2}{|c|}{ tissue* } & \multirow{2}{*}{$\frac{\text { soil }}{\text { range }}$} & \\
\hline & mean & mean & & \\
\hline Wielkopolskie & $\begin{array}{l}\mathrm{L}=0.89 \\
\mathrm{~K}=3.85\end{array}$ & 0.19 & n.d.- -0.57 & Tomza-Marciniak et al. (2010) \\
\hline Kujawsko-pomorskie & $\begin{array}{l}\mathrm{L}=0.73 \\
\mathrm{~K}=3.28\end{array}$ & 0.14 & $0.04-0.33$ & Borowska et al. (2007) \\
\hline Podlaskie & $\begin{array}{l}\mathrm{L}=0.64 \\
\mathrm{~K}=4.13\end{array}$ & 0.39 & $0.16-1.57$ & Biernacka and Małuszyński (2006) \\
\hline Śląskie & $\begin{array}{l}\mathrm{L}=0.65 \\
\mathrm{~K}=4.25\end{array}$ & 0.23 & $0.06-0.81$ & Biernacka and Małuszyński (2006) \\
\hline
\end{tabular}

* this study

nificant differences were determined using Duncan's test. The correlation between liver and kidney selenium concentrations in the studied animals was determined by calculating Pearson's coefficient of correlation $\left(r_{x, y}\right)$.

\section{Results}

The results for mean concentrations of selenium in the analysed wild boar organs are shown in Tables 1 and 2. Hepatic and nephric selenium concentration ranged 0.036 to $0.626 \mu \mathrm{g} / \mathrm{g} \mathrm{w}$.w. and 0.322 to 4.286 $\mu \mathrm{g} / \mathrm{g}$ w.w, respectively. Mean selenium concentration in the investigated wild boars from Poland was 0.230 $\mu \mathrm{g} / \mathrm{g}$ w.w. in the liver and $1.327 \mu \mathrm{g} / \mathrm{g}$ w.w. in the kidneys.

It was found that the concentration of Selenium in the organs of wild boars differed depending on their geographic origin (Table 3). The mean selenium concentration in the liver was highest in animals from the Świętokrzyskie province, and over 3.5-fold lower in the Pomorskie province ( 0.481 vs. $0.128 \mu \mathrm{g} / \mathrm{g}$ w.w.). The mean selenium concentration in the kidneys was highest in the Świętokrzyskie province and over 4-fold lower in the Pomorskie province (2.693 vs. $0.663 \mu \mathrm{g} / \mathrm{g}$ w.w.).

\section{Discussion}

Referring to the results obtained, it can be assumed that the geochemical nature of the soil-forming substratum (soil parent rock) is a decisive factor affecting on Se levels in animals. The area of the Świętokrzyskie province is dominated by chernozems, which are considered the most fertile soils. They are rich in humus and occur in compact areas. As reported by Kabata-Pendias and Pendias (1999), increased Se concentrations are usually found in soils that are rich in organic matter and iron compounds. In general, the selenium content of plants reflects its levels in the soil and in many cases it is positively correlated to the total content of this element in animals (Kabata-Pendias and Pendias 1999) (Table 3). However, analysis of available data on the concentration of Se soil in different areas of Poland in relation to the obtained concentration of Se in the kidneys and livers of wild boar, did not show relationship between these parameters. The reasons for this may be several. The most important are: first, a comprehensive study on the soil content in the Se has not been carried out in Poland and the available studies are fragmentaric and may not fully reflect the existing situation; second, there may be a number of factors affecting the bioavailability of Se in the soil-plant-animal system.

Wild boars are omnivorous and take advantage of all available food sources (Herrero et al. 2006). When foraging, they dig into the soil to a considerable depth, often over large areas. Wild boars feed mainly on plants, which account for $80-90 \%$ of the diet, with between 2 and 11\% from animal sources (Fronseca 2008, Massei and Genov 2004). Wild boars in the Swiętokrzyskie province were hunted in an area where soils are considered the least contaminated with sulphur (1.9\%) (Kamiński 2006). The increased sulphur content of the soil decreases the availability of selenium to plants while reducing its content in animal food.

The low content of selenium in wild boars from the Pomorskie province may be attributed to the effect of the anthropogenic factor. In the area from which the samples were collected a chemical plant producing phosphate fertilizers (containing $\mathrm{Cd}$ and $\mathrm{Pb}$ ) as well as the second largest fuel and oil refinery in Poland are located. These industries are the main source of atmospheric pollutants in this area. Toxic metals accumulate in the soil, plants and water communities, and disturb the biological equilibrium of ecosystems. The highest amounts of heavy metals enter the animal body through ingestion (Silva et al. 2005). The body's absorption of selenium depends on 


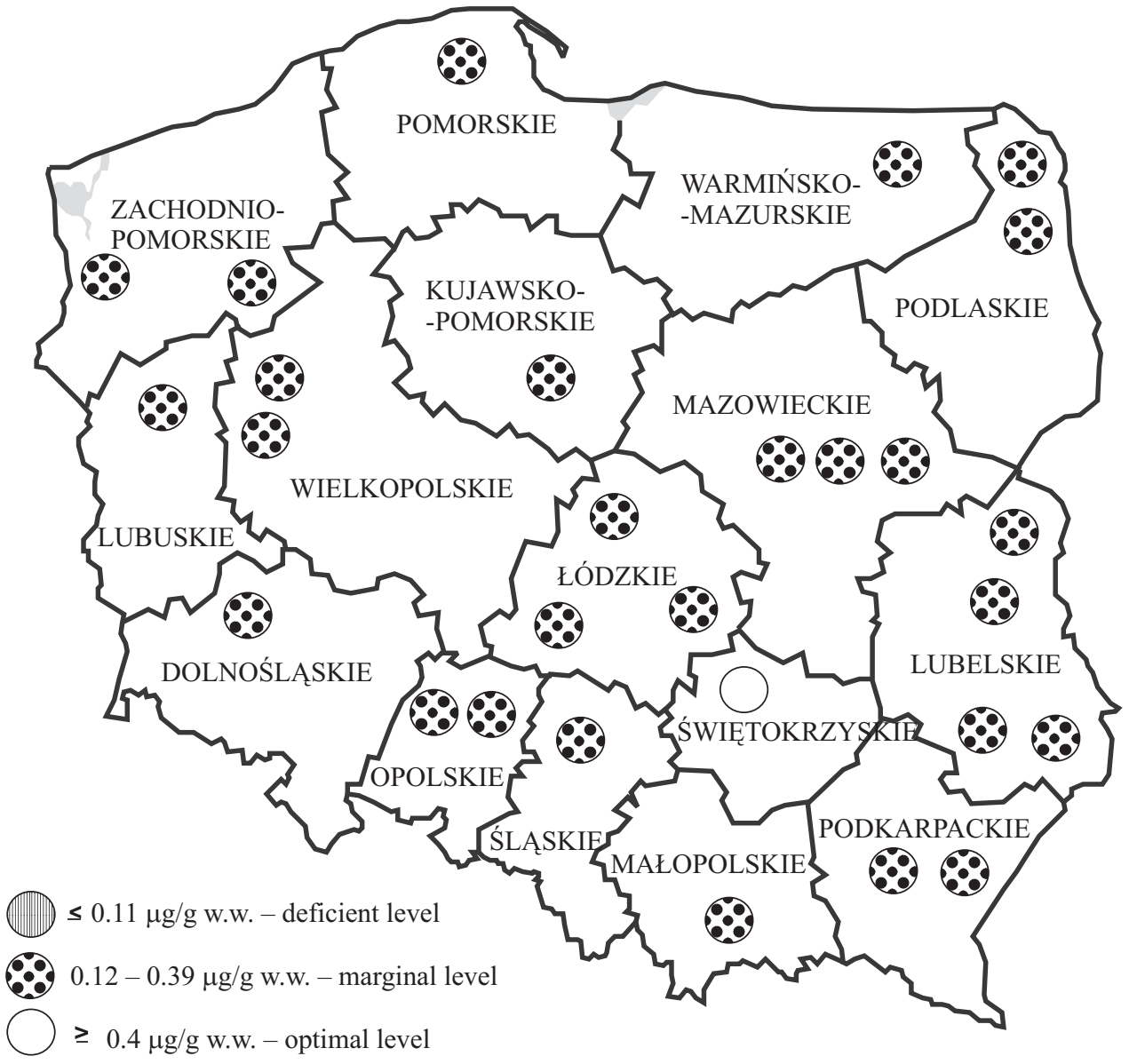

Fig. 1. Mean selenium concentration ( $\mu \mathrm{g} / \mathrm{g}$ w.w.) in th liver of wild boars.

the chemical composition of the food and on the interactions between Se and other elements. Selenium is antagonistic to $\mathrm{Cd}$ and $\mathrm{Pb}$. The presence of these metals reduces the absorption of dietary selenium. That is why the organs of wild boars living in this area may be so low in selenium. This theory is supported by Dudka (1992) who reported high soil selenium levels $(0.4-0.6 \mathrm{mg} / \mathrm{kg})$ in the same area. The high selenium concentration in the surface layer of the soil suggests that anthropogenic factors have a considerable effect. It should be mentioned that a query of scientific literature revealed no studies providing reference values for wild boars. Due to the lack of such data, some authors compare their findings to the reference values of pigs (Pilarczyk et al. 2010) while indicating that the results of environmental studies should not be compared to the results obtained with pigs because of the large differences in the diets of these animals that translate directly into Se concentrations in their body. Pigs are kept in livestock buildings and selenium is one of the trace elements added to their diets in Poland.

According to Puls (1994) the biochemical criteria used to diagnose selenium deficiency in pig liver are as follows: below $0.11 \mu \mathrm{g} / \mathrm{g}$ w.w. - deficient; from 0.12 to $0.39 \mu \mathrm{g} / \mathrm{g}$ w.w. - marginal level; more than $0.40 \mu \mathrm{g} / \mathrm{g}$ w.w. - optimal level for animals. Based on these criteria, our study showed optimal liver selenium levels in wild boars from the Świętokrzyskie province and marginal levels in all the other provinces (Fig. 1).

Pollock (2005) holds the view that liver selenium concentration is a better indicator of the body's selenium status compared to the kidney concentration. The liver is the main organ responsible for selenium homeostasis in the body. Selenoproteins (including selenium-dependent glutathione peroxidase) are synthesized and distributed in the liver. When selenium is deficient, it is first sourced from the liver. This theory is corroborated by studies performed in the Lubelskie, Małopolskie and Dolnośląskie provinces. Se levels in wild boars from these areas were found to be at marginal levels in the liver and at optimal in the kidneys. This relationship is probably due to the fact that the liver and kidneys play a critical role in trace element metabolism. The largest number of positive correlations between toxic and essential elements is found for these organs (López-Alonso et al. 2004). The samples obtained in our study from wild boars in the Dolnośląskie province originated from a polluted area (Legnica-Głogów Copper District, a brown coal mine, 


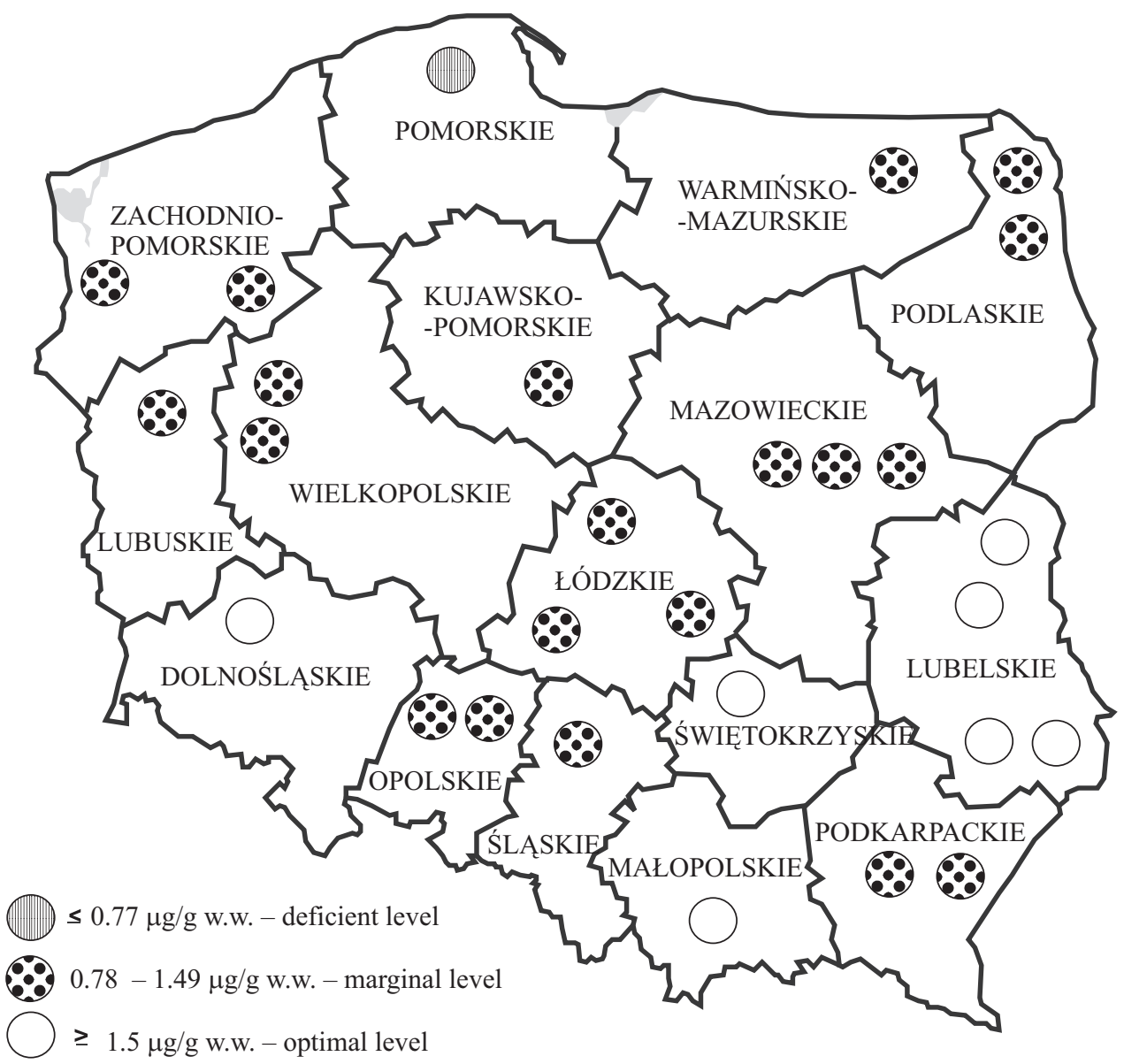

Fig. 2. Mean selenium concentration ( $\mu \mathrm{g} / \mathrm{g}$ w.w.) in the kidneys of wild boars.

copper ore deposits containing silver, nickel, cobalt, vanadium, zinc and lead, as well as metal works). Upon entering the body, metals are bound by plasma proteins, after which they are moved to the liver and kidneys, which are the target accumulation organs (Orłowski 2008). In these organs metals are bound by metallothionein (MT), which is synthesized in the presence of selenium-containing glutathione peroxidase (GSHPx) (Shimuzu and Morita 1990). That is why selenium reserves, which are mainly accumulated in the liver, are first mobilized from the body. As a result, selenium deficiency first affects the liver. Selenium and toxic metals $(\mathrm{Pb}, \mathrm{Cd}, \mathrm{Hg})$ form selenides which are excluded from biochemical processes (liver). Because these compounds are not readily soluble (problems with excretion through the kidneys), they accumulate in the kidneys (Shimuzu and Morita 1990, Orłowski 2008). This is probably why kidney selenium concentrations show an optimal level in wild boars from the Dolnośląskie province.

Apart from forest and meadow vegetation, wild boars often graze on field crops, causing major damage to maize, potatoes, cereals, and other crops. Cultivated plants can make up one-third of the wild boar's diet, with cereals and potatoes occurring in equal amounts. In the Lubelskie and Małopolskie provinces the samples were collected from agricultural land where considerable quantities of phosphate and nitrogen fertilizers are used. Again, one of the reasons for the optimal concentration of selenium in the kidneys of the wild boars from these areas may be the presence of toxic metals $(\mathrm{Pb}, \mathrm{Cd})$, and the subsequent formation of insoluble selenides which would accumulate in the kidneys.

Other authors believe, however, that the ratios between kidney and liver selenium content are what matters. As reported by Oh et al. (1976), lambs fed a selenium-deficient diet always had a higher concentration of this element in the kidneys than in the liver, with a reverse situation occurring when lambs received a selenium-rich diet. In our study, higher selenium concentrations in the liver than the kidneys were not found in any of the provinces under analysis, with Se concentrations in the liver several-fold lower than in the kidneys, possibly indicating that the dietary content of this element was too low or the selenium form was not readily available.

According to Puls (1994) the biochemical criteria used to diagnose selenium deficiency in pig kidneys are as follows: below $0.77 \mu \mathrm{g} / \mathrm{g}$ w.w. - deficient; from 
0.78 to $1.49 \mu \mathrm{g} / \mathrm{g}$ w.w. - marginal level; more than 1.50 $\mu \mathrm{g} / \mathrm{g}$ w.w. - optimal level for animals. When comparing our results obtained for kidney Se concentrations in wild boars to the criteria cited above, we found that this element was deficient only in the Pomorskie province, with optimal levels in the Świętokrzyskie, Dolnośląskie, Lubelskie and Małopolskie provinces. Marginal levels were observed in the other provinces (Fig. 2).

The mean selenium concentration obtained in our study for wild boars from the Zachodniopomorskie province was comparable to the values reported by $\mathrm{Pi}$ larczyk et al. (2010). This area has long been considered deficient in selenium (Pilarczyk et al. 2009, 2010). The mean liver Se concentration obtained in our study for wild boars from the Zachodniopomorskie (0.527 $\mu \mathrm{g} / \mathrm{g}$ d.w.), Warmińsko-Mazurskie (0.453 $\mu \mathrm{g} / \mathrm{g}$ d.w.), Pomorskie (0.437 $\mu \mathrm{g} / \mathrm{g}$ d.w.), Mazowieckie $(0.562 \mu \mathrm{g} / \mathrm{g}$ d.w.) and Łódzkie provinces $(0.580 \mu \mathrm{g} / \mathrm{g}$ d.w. $)$ was also comparable with the findings of Reglero et al. (2009) who reported $0.453 \mu \mathrm{g} / \mathrm{g}$ d.w in the liver of wild boars from southern Spain (Sierra Madrona) and $0.589 \mu \mathrm{g} / \mathrm{g}$ d.w. (Montes de Ciudad Real). In turn, the liver Se concentration in wild boars from the Lubelskie (1.179 $\mu \mathrm{g} / \mathrm{g}$ d.w.) and Małopolskie provinces (1.278 $\mu \mathrm{g} / \mathrm{g}$ d.w.) were comparable with the results of Rodriguez-Estival et al. (2011) obtained in the liver of wild boars $(1.3 \mu \mathrm{g} / \mathrm{g}$ d.w.) in the Montes de Ciudad Real region (province of Ciudad Real). The liver Se concentrations in wild boars from the Wielkopolskie (0.888 $\mu \mathrm{g} / \mathrm{g}$ d.w.), Dolnośląskie $(0.740 \mu \mathrm{g} / \mathrm{g}$ d.w.) and Kujawsko-Pomorskie provinces $(0.729 \mu \mathrm{g} / \mathrm{g}$ d.w. $)$ were comparable with values obtained by Nevado et al. (2012) in southern Spain (0.835 $\mu \mathrm{g} / \mathrm{g}$ d.w.).

The lack of reference data for organ concentrations of selenium in wild boar makes a conclusive judgment impossible. According to Pilarczyk et al. (2010) monitoring of Se levels in the liver and kidneys of wild boars may in the future form a basis for determining reference values and developing a prophylactic programme for animals living in selenium deficient areas.

\section{Conclusions}

Considerable differences were found for organ selenium concentrations in the wild boars according to geographical location. Liver and kidney concentrations of selenium were highest in the wild boars from south-eastern provinces and lowest in animals from the northern provinces. Most of Poland's area is environmentally deficient in this trace element, as evidenced by marginal selenium levels in the organs of the wild boars.

\section{References}

Beytut E, Karatas F, Beytut E (2002) Lambs with white muscle disease and selenium content of soil and meadow hay in the region of Kars, Turkey. Vet J 163: 214-217.

Biernacka E, Małuszyński MJ (2006) The content of cadmium, lead and selenium in soils from selected sites in Poland. Polish J Environ Stud 15: 7-9.

Dudka S (1992) Establishing baseline concentrations of major and trace elements in surface soils of Poland. Habilitation thesis. IUNG, Puławy.

Flueck WT, Smith-Flueck J (2008) Age-independent osteopathology in skeletons of a South American cervid, the Patagonian huemul (Hippocamelus bisulcus). J Wildl Dis 44: 636-648.

Flueck WT, Smith-Flueck JM, Mionczynski J, Mincher B (2012) The implications of selenium deficiency for wild herbivore conservation: a review. Eur J Wildl Res 58: 761-780.

Fronseca C (2008) Winter habitat selection by wild boar Sus scrofa in southeastern Poland. Eur J Wildl Res 54: 361-366.

Grzebuła S, Witkowski P (1977) The determination of selenium trace levels in biological materials with fluorometric method. Selenium determination in tissues and bodily fluids. Pol Arch Weter 20: 125-138.

Hartikainen H (2005) Biogeochemistry of selenium and its impact on food chain quality and human health. J Trace Elem Med Biol 18: 309-318.

Herrero J, García-Serrano A, Couto S, Ortuño VM, Garcta-González R (2006) Diet of wild boar Sus scrofa L. and crop damage in an intensive agroecosystem. Eur J Wildl Res 52: 245-250.

Kabata-Pendias A, Pendias H (1999) Biochemistry of trace elements. 2nd ed., Wydawnictwo Naukowe PWN.

Kamiński Z (2006) Soil. In: Janiszewska M (ed) State of the environment in the region Świętokrzyskie in 2005. Report. Regional Inspectorate for Environmental Protection, Kielce, pp 141-152.

López Alonso M, Montaña FP, Miranda M, Castillo C, Hernández J, Benedito JL (2004) Interactions between toxic $(\mathrm{As}, \mathrm{Cd}, \mathrm{Hg}$ and $\mathrm{Pb})$ and nutritional essential $(\mathrm{Ca}, \mathrm{Co}$, $\mathrm{Cr}, \mathrm{Cu}, \mathrm{Fe}, \mathrm{Mn}, \mathrm{Mo}, \mathrm{Ni}, \mathrm{Se}, \mathrm{Zn}$ ) elements in the tissues of cattle from NW Spain. Biometals 17: 389-397.

Mäkelä-Kurtto R, Sippola J (2002) Monitoring of Finnish arable land: changes in soil quality between 1987 and 1998. Agricul Food Sci Finland 11: 273-284.

Massei G, Genov PV (2004) The environmental impact of wild boar. Galemys 16: 135-145.

Nevado JJB, Martyn-Doimeadios RCR, Mateo R, Rodríguez-Fariñas N, Rodríguez-Estival J, Ropero MJP (2012) Mercury exposure and mechanism of response in large game using the Almaden mercury mining area (Spain) as a case study. Environ Res 112: 58-66.

Oh SH, Sunde RA, Pope AL, Hoekstra WG (1976) Glutathione peroxidase response to selenium intake in lambs fed a Torula yeast-based, artificial milk. J Anim Sci 42: 977-983.

Orłowski C (2008) Metals. In: Piotrowski J (ed) Fundamentals of toxicology. Wydawnictwo Naukowo-Techniczne, Warszawa, pp 166-169.

Pilarczyk B, Balicka-Ramisz A, Ramisz A, Adamowicz E, Pilarczyk R, Tomza-Marciniak A, Bąkowska M (2009) 
Selenium concentration in liver and kidney of free living animals (roe and red deer) from West Pomerania (Poland). Eur J Wildl Res 5: 279-283.

Pilarczyk B, Hendzel D, Pilarczyk R, Tomza-Marciniak A, Błaszczyk B, Dąbrowska-Wieczorek M, Bąkowska M, Adamowicz E, Bujak T (2010) Liver and kidney concentrations of selenium in wild boars (Sus scrofa) from northwestern Poland. Eur J Wildl Res 56: 797-802.

Pilarczyk R, Wójcik J, Czerniak P, Sablik P, Pilarczyk B, Tomza-Marciniak A (2013) Concentrations of toxic heavy metals and trace elements in raw milk of Simmental and Holstein-Friesian cows from organic farm. Environ Monit Assess 185: 8383-8392.

Pollock B (2005) Trace elements status of white-tailed red deer (Odocoileus virginianus) and moose (Alces alces) in Nova Scotia. Canadian Cooperative Wildlife Health Centre - Newsletters \& Publications, Lincoln.

Przybylski A (2008) The key to determining the age of a deer, fallow deer, roe deer, mouflon and wild boars, Zachodni Poradnik Łowiecki, Poznań, pp 40-49.

Puls R (1994) Mineral levels in animal health. Diagnostic data, 2nd ed., Sherpa International, British Columbia Clearbrook.

Reglero MM Taggart MA, Monsalve-Gonzhlez L, Mateo $R$ (2009) Heavy metal exposure in large game from a lead mining area: effects on oxidative stress and fatty acid composition in liver. Environ Pollut 157: 1388-1395.

Rodríguez-Estival J, Martinez-Haro M, Monsalve-González L, Mateo R (2011) Interactions between endogenous and dietary antioxidants against $\mathrm{Pb}$-induced oxidative stress in wild ungulates from a $\mathrm{Pb}$ polluted mining area. Sci Total Environ 409: 2725-2733.

Shimizu M, Morita S (1990) Effects of fasting on cadmium toxicity, glutathione metabolism, and metallothionein synthesis in rats. Toxicol Appl Pharmacol 103: 28-39.

Silva AL, Barrocas PR, Jacob SC, Moreira JC (2005) Dietary intake and health effects of selected toxic elements. Braz J Plant Physiol 17: 79-93.

Tomza-Marciniak A, Bąkowska M, Pilarczyk B, Semeniuk M, Hendzel D, Udała J, Balicka-Ramisz A, Tylkowska A (2010) Selenium concentration in soil and selected tissues of roe deer (Capreolus capreolus) from Wielkopolska region. Acta Sci Pol Zootechnica 4: 251-260.

Terry N, Zayed AM, de Souza MP, Tarun AS (2000) Selenium in higher plants. Annu Rev Plant Physiol Plant Mol Biol 51: 401-432.

Yläranta $T$ (1990) The selenium content of some agricultural crops and soils before and after the addition of selenium to fertilizers in Finland. Ann Agric Fen 29: 131-139. 